The Philosophical Journal of Conflict and Violence

Vol. I, Issue 2/2017

(C) The Authors, 2017

Available online at http://trivent-publishing.eu/

\title{
Fornari, Giuseppe. A God Torn to Pieces. The Nietzsche Case
}

East Lansing: Michigan State University Press, 2013. xvii + 162 pp.

One of the most influential yet misunderstood thinkers, Friedrich Nietzsche is the subject of Giuseppe Fornari's work, A God Torn to Pieces: The Nietzsche Case. In the book, Fornari offers the reader a profound and unique insight into Nietzsche's life, struggles, and ultimate demise through his analysis of testimonies from friends, psychiatric accounts, and Nietzsche's own writings. Fornari aims to explore the link between Nietzsche's background, philosophy, and eventual ruin; debunk previous flawed assumptions regarding these issues; and establish that Nietzsche's revolt against Christianity drove him to become not only Dionysus, but Christ. For Fornari, reaching a deep understanding of Nietzschean ideas is fundamental to comprehending and learning from some of the grave mistakes of European history.

Although Fornari uses his earlier collaboration with René Girard as a starting point for the book and draws heavily on Girardian ideas, he claims that his colleague's analysis of Nietzsche is "far from being complete or completely satisfactory," (2) and his study ultimately differs in content, method, and evaluation. With regard to method, Fornari controversially sets out to analyse the clinical reports that detail Nietzsche's illness, claiming these are integral to an understanding of Nietzsche. His evaluation of Nietzsche differs from Girard's in several ways, perhaps most significantly in his analysis of both the cause and significance of Nietzsche's madness. Fornari stresses the importance of including Nietzsche's childhood, personal relationships, and episodes of insanity in studies of Nietzsche, widening the well of evidence from which conjectures about Nietzsche's madness can be drawn. Furthermore, Fornari argues that Nietzsche cannot be held responsible for the adoption of his ideas by the Nazi Party, regarding him rather as "a kind of early-warning device" ( $\mathrm{x}$ ) than deserving of blame.

Fornari begins by outlining his goal to exhume, metaphorically of course, Nietzsche in order to conduct a meticulous post-mortem examination that works to better previous "botched" attempts. With the stage set, Fornari delves into Nietzsche's life, examining his exploits in great detail and treating his biography like a labyrinth to be navigated and conquered. For the most part, Fornari depicts Nietzsche as a sympathetic character who is simultaneously the protagonist and antagonist of his own story. In the first chapter, "The Hunt for the Whale", Fornari compares Nietzsche to Captain Ahab from Moby Dick, and this comparison persists throughout the book. As well, Nietzsche is compared to the

This is an Open Access article distributed in accordance with the Creative Commons Attribution Non Commercial (CC-BY-NC-ND 4.0) license, which permits others to copy or share the article, provided original work is properly cited and that this is not done for commercial purposes. Users may not remix, transform, or build upon the material and may not distribute the modified material (bttp:// creativecommons.org/licenses/by-nc/4.0/) 
eponymous Moby Dick, which establishes him as both the hunter and prey: a man subconsciously hell-bent on a course of self-destruction. This double identity is a significant theme of the work. In chapter three, "The Philosopher and his Double," Fornari peels back the onion layers further by dissecting Nietzsche's complex and destructive relationship with Wagner. Coupled with his unrequited love for Wagner's wife, Cosima, Nietzsche's failure to emulate Wagner's musical genius causes his initial admiration to morph into a professional and social rivalry and, eventually, a deep loathing for his mentor. The Girardian notion of a model-obstacle is precisely what Wagner becomes for Nietzsche. Nietzsche cannot defeat his rival because to do so would be to destroy him as an idol. Their relationship also constitutes a double bind, with Nietzsche simultaneously admiring and detesting Wagner. The crux of their changing relationship was the year when Wagner was highly and universally praised by society while Nietzsche's attempts, in stark contrast, were rejected. Eventually, his hopeless envy of Wagner and unrequited love for Cosima turned Nietzsche into a green-eyed monster. One is reminded of Frankenstein's monster, whose suffering at the hands of cruel men and their refusal to accept his efforts to assimilate turned him to envy, malice, and self-hate.

If there is one takeaway message from this chapter, it is "poor Nietzsche." An absolutely stinging review from Hans von Bülow prompts a saccharine response from Nietzsche, which renders him obsequious, a slave to the opinions of others, and shows his total lack of self-confidence. Those whom Nietzsche wished to impress laughed at his expense, and he was transfigured into a cloying lap-dog, who wrote self-deprecating letters to his tormentors; his attempts to enter the realm of talented musicians made him an object of ridicule. As reported by his sister, Nietzsche became "the God, torn to pieces by his enemies" (102). Although agreeing with Girard that Nietzsche's relationship with Wagner is significant, Fornari places less emphasis on it as the ultimate root of his madness and looks to Nietzsche's childhood and relationship with his father to establish causation.

Interestingly, Fornari asserts that the death by brain tumour of Nietzsche's biological father, Carl Ludwig, was complicit in, and even a catalyst for, the philosopher's illness. He suggests that Nietzsche's syphilis was used as an excuse to cover up the truth: a scapegoat that masks the true reality of his descent into insanity. Claiming that this connection was missed by Girard and other critics (partially to avoid relying on Freudian psychology), Fornari proposes that Nietzsche's psyche became diseased through the loss of a true paternal influence. This assessment, however, is anti-Freudian, as Fornari stresses that Nietzsche felt only filial affection for his genitor. Nietzsche's interest and eventual obsession with pseudo-father Wagner was birthed from the lack of a father figure in his early years.

Fornari's exposition of Nietzsche's mental illness in chapter two, "The Eternal Recurrence of Madness", brings to light a new and fascinating representation of the philosopher. While Girard views Nietzsche's mental illness as a consequence of his double bind and complete denial of Christian values, Fornari sees it as a gateway through which we can access essential Nietzschean philosophy. Perhaps the most disturbing passages of the work are the glimpses into Nietzsche's time at the asylum in which he was contained in the later years of his life. Letters from Nietzsche's close friends, such as Peter Gast and Franz 
Overbeck, are referenced alongside medical accounts from the asylum, depicting Nietzsche's most maniacal moments of madness. Although disconcerting and sympathyinducing, the passages are illuminating and provide a unique psychological lens through which to view the great thinker. Rather than ignoring or minimising the importance of Nietzsche's psychological episodes, Fornari claims that it is during them that his genuine self became apparent; Nietzsche's true personality is apparent through his behaviour in his last days. One of the insights Fornari gleans from the accounts is the symbolism of Nietzsche's increasing obsessions with sex, food, and excrement. His desire for sex, Fornari suggests, is a symbol not only of Nietzsche's lust for Cosima, but also a representation of life itself, while his fixation on food, excrement, and urination is a behavioural manifestation of his obsession with power. Ultimately, it was through his insanity that Nietzsche was finally able to comprehend the feeling of ressentiment he so abhors from the perspective of the victim.

The fourth, fifth and sixth chapters of the book deal with Nietzsche's relationship with Christ and Dionysus, his transfiguration into the latter, through which he becomes the Antichrist, and his overall relationship with Christianity. Fornari builds on the Girardian belief that Nietzsche correctly analysed the analogous nature of the Christ figure of Christianity and the character of Dionysus in paganism, but essentially chose the wrong one to emulate. Fornari suggests that Nietzsche's final demise was primarily spiritual, partially caused by the contraposition between the two divine characters and Nietzsche's selfidentification with both, the latter which he attempted to deny.

In chapter four, "The Foundation of Dionysus," Fornari puts forward the claim that Nietzsche hated Christ and details the former's smear campaign against the latter. Again, Fornari adheres to the Girardian approach that attributes Nietzsche's destruction to his loathing of the Christian tenet of pitying the victim, or scapegoat, who dies at the hands of the mob. Building on Girardian ideas about Nietzsche's refusal to accept Christ's forgiving nature, Fornari explains that Nietzsche's dismissal of Christian virtues led him to latch on to a mimetic rivalry between Christ and Dionysus, resulting in an attempt to transfigure into the latter, who becomes synonymous with the Antichrist or Satan.

Nietzsche's growing disgust at Christianity and Christ is explored in chapter five, "The Antichrist and the Crucifixion." Fornari explains that Nietzsche could "only remain deaf and blind at the incandescent core of the difference that he had intuited and forced into the open, a sacrificial core that puts man in contact with God through the real repetition of his history, origin, and guilt" (90). Nietzsche gained an understanding of sacrifice through the stories of Christ and Dionysus, but did not appreciate the redemptive properties of the crucifixion and, from this, the restorative power and virtue of forgiveness. Fornari argues that Christ replaced Wagner as the double bind that Nietzsche both detested and was drawn to, and that he eventually decides must be destroyed.

Chapter six, "What None Have Perceived," details Nietzsche's realisation that Dionysus is the secret to human origin, which continued his decline. Tragically caught in the double bind of identifying with Christ and Dionysus, Nietzsche was the victim of persecution, but he could not allow self-pity due to his beliefs. As a disciple of Dionysus, Nietzsche wanted to celebrate the natural state of violence and shun the Christ-like ressentiment that 
disgusted him. Slave to his "deranged divination transference" (101) to a Dionysian figure, Nietzsche sacrificed himself. Fornari concludes that Nietzsche was much closer to Christ than many, including Nietzsche himself, realised.

Through the accounts of Nietzsche's trials and tribulations, the author presents the subject's downfall as terminal, taking what seems on many occasions to be a fatalistic approach to his life. Establishing him as a tragic figure, Fornari hints that Nietzsche's fate was inexorable - a perspective that seems to remove much individual responsibility from Nietzsche and place it squarely on external factors. As a result, the reader shares the "pity and dismay" (18) felt by Fornari as Nietzsche's journey continues. It is as if we are reading a Greek tragedy for the umpteenth time; we know the fate of the protagonist but are unable to alter the course of his ominous journey. Ultimately, this "buffoon in whom the truth speaks" or "clown-God," (4) as Nietzsche describes himself, precipitates his own downfall through a desire to augment himself to a god-like figure.

One of the central claims of the text is that studying Nietzsche is vital to reaching a deeper understanding of Christianity. Following in Girard's footsteps, Fornari speaks to Nietzsche's recognition that Christianity distinctively promotes mercy and forgiveness as virtues. While this distinctive feature was interpreted negatively by Nietzsche to mean that Christianity corrupted the human soul, to Fornari it is an insight into the uniqueness of the religion. What Nietzsche lacked, Fornari claims, was the virtues of love and forgiveness that are necessary for survival. He states, "those ... who refuse to believe that they, too, have been forgiven; and so, in order to see, to embrace, this inaccessible God, they are reduced to madness." (118).

Fornari frequently alludes to the importance of interpreting Nietzsche for not only Christianity but contemporary society as a whole. He is clear to state that Nietzsche should not be blamed for the Nazi party adopting his ideas and that, in fact, his work should have a positive effect on society, waking people from "dogmatic slumber." (x). Nietzsche, Fornari maintains, was the peal of alarm bells that tolled a warning about what was to come in Europe. Nietzsche's work is therefore not only philosophically but also historically important and inextricably bound up to the tragedy of the Holocaust.

Although occasionally praising what he deems to be accurate understandings of Nietzsche (such as his positive review of Otto Weininger's commentary on Nietzsche's relationship with Christianity), the author has many disparaging remarks to make about previous interpretations. He rejects and disparages Thomas Mann's "minimalist" claim that Nietzsche's madness was caused by syphilis, claiming that the hypothesis lacks both medical and biographical basis and ignores some key relevant factors such as Carl Ludwig's premature death. Fornari denies Nietzsche's infamous brothel story, deeming it a "fabrication" (29) constructed by Mann, and claims that Verrecchia's interpretation of Nietzsche's The Antichrist is ignorantly correct, stating that he is "unaware of how exactly his definition hits the mark." (82). It is clear that the author believes these past misdiagnoses are both ill-formed and irresponsible.

Despite offering a convincing portrayal of Nietzsche's deterioration, there are some difficulties with taking everything Fornari concludes as decisive. The main challenge the reader might bring to Fornari is one that he himself realises: the inevitable difficulty of 
interpreting evidence. Not only are some of the original sources biased, misleading, or incomplete, but Nietzsche's own writings take different forms (books, letters, and poetry written in various stages of his mental, emotional, and physical decline). The question of which of Nietzsche's writings should be examined can be posed. Should his poetry be given the same importance as his memoirs? The author states that Nietzsche should be "interpreted metaphorically where he ought first to be taken literally, and interpreted literally where he ought not to be," (5) but it is a challenge to determine which approach should be adopted for each work. As Fornari states: "once the right key to interpretation has been identified, Nietzsche's own writings and documents about his life provide what seems to be almost overwhelming confirmation, compelling us to see his ideas and fate with fresh eyes." (11). The question remains as to whether Fornari's key fits Nietzsche's lock.

Besides insightful and well-researched conclusions, the author, working with translator Keith Buck, has a wonderful way with words, and I was frequently struck by the beauty of the language employed. Through effective metaphors, clever similes, and generally poetic prose, Fornari presents a work that is compelling, relevant, and beautifully-written. Although stylistically Fornari's prose are elegant, they are also dense, and his tendency to use hyperbolic language may not gel well with readers who prefer a more concise style. Passages often needing re-reading to extrapolate the full meaning. The text is certainly much easier to digest if you are at least at an intermediate level of Nietzschean study, if not a connoisseur of the philosopher.

The author honestly reflects that this examination was "excruciatingly painful," (103) and that compassion helped him avoid suffering the "hellish journey" (xv) of exploring Nietzsche, comparing his book-writing experience to Dante's infernal quest. He does not shy away from tackling this topic head on and, as a result, has produced a stark and candid study that holds Nietzsche up to a mirror, rather than painting a fanciful and laudative portrait. Fornari's attempt to break down the assumptions and stigma that circle Nietzsche's work simultaneously highlight the importance of reading it carefully and taking it seriously. 